\title{
Thinking Styles of Adolescences In Relation To Their Personality Types
}

\author{
Dr. Vineeta, \\ Asstt. Professor inHome Science M.P. Government Degree College, Sikandra Rao (Hathras) U.P. India
}

\begin{abstract}
The present investigation aimed to study the thinking styles of adolescences in relation to their personality types (Extrovert and Introvert). For the purpose a sample of 198 male and 173 female was selected from Senior Secondary Schools from Aligarh District of U.P. by using accidental technique of sample selection. In the present study the Normative Survey method of research was used. Thinking Style Inventory constructed by Sternberg \& Wagner and Maudsley Personality Inventory (M P I) constructed by Eysenck were used to collect the data. Results revealed that the Extrovert and introvert type of Adolescences did not exhibit significant differences in their all thinking styles namely - integrated, legislative, executive, judicial, monarchic, hierarchic, oligarchic, anarchic, global, local, internal, external, liberal and conservative style of thinking.
\end{abstract}

\section{Introduction}

Thinking style refers to the way an individual prefers to process and manage the intellect and knowledge (Zhang \& Sternberg, 2000). Sternberg (2009) defined 5 dimensions, which are functions, forms, levels, scopes and leanings, and 13 thinking styles grouped under these dimensions in the theory of mental selfgovernment. Functions refer to the individual preference of initiating new ideas and practice, setting regulations or evaluating. Legislative, executive and judicial thinking styles are included in this dimension. The second dimension, which is forms, includes monarchic, hierarchic, oligarchic and anarchic styles and refers to how individuals prefer to approach the life events. Levels, including global and local thinking styles, identify the individuals focusing on abstract and large issues or the individuals paying attention to concrete issues and details. The forth dimension is scopes, which embrace internal and external styles, and refers to preference of individuals to be introverts or extraverts. Leanings, which include liberal and conservative thinking styles, is the fifth dimension defined by Sternberg and associated with the flexibility of individuals about transcending existing rules or adherence to the rules. In addition Zhang and Sternberg (2006) grouped 13 thinking styles into 3 types; Type I styles are perceived more positive and adaptive and include legislative, judicial, hierarchical, global, and liberal styles whereas Type II styles are more negative and less adaptive and include executive, local, monarchic, and conservative styles. Finally, Type III styles are neither positive nor negative but adaptable due to the requirements of a situation and include anarchic, oligarchic, internal, and external.

Global thinking style is characterized by concentrating on the big picture, ignoring details, preferring abstractness, enjoying generalization, conceptualizing and thinking (Sternberg, 2009; Zhang \& Sternberg, 2001). Whereas local style identify focusing on details, preferring concreteness, avoiding conceptual analysis and experiencing difficulty in distinguishing important from unimportant (Fer, 2005; Sternberg, 2009).

The studies on thinking styles can be clustered under three approaches. First group of studies focus on the relationship between thinking styles and personal variables, such as socioeconomic status, birth-order and age, and environmental characteristics, exemplified with learning settings, parental thinking styles and preferred extracurricular activities. The second group explores the role of thinking styles on different aspects, such as academic achievement, cognitive and psychosocial development of student development and learning. The third group investigates how thinking styles correspond to other style constructs, for instance Biggs' learning approaches and Holland's career personality types (Zhang \& Sternberg, 2006).

Thinking styles frequently studied in educational concepts since thinking is the core of education and considered as being one of the components which shape the learning environment. In addition, in literature there are recent research which focused on thinking styles and technology usage (Kao, Lei, \& Sun, 2007). But in psychology this concept did not attract much attention, although the way individuals think leads to thoughts which is one of the three main aspects of human beings as stated by Cloninger (2008). Thinking styles are cognitive preferences, which affect how an individual behaves and feels, and selected as a cognition representative for this study

Educators hold that students learn and think in unique individualized ways whether they belong to school, college or university level. Secondary education is becoming increasingly important in every society of developed or developing countries. Particularly a society of people who make mid life career changes or advance their skills or who must work out of necessity or those whose leisure time permit education, all 
contribute to increase demand of education through formal or non-formal modes. Therefore the question of how to teach adolescences in more effective and efficient ways is becoming pertinent day-by-day.

In search of solution of teaching problems adolescences, some work has been done on thinking styles of students in foreign countries. But in India no such attempt has been made so far. Hence there is a considerable scope to probe the area styles of thinking of adolescences in socio-cultural milieu of Indian society.

Thinking styles are very important components of the learning processes of college education. Their understanding is highly desirable if we have to obtain a comprehensive picture of learning processes of adolescences and to base our teaching efforts on the knowledge of the same in order to inject quality control in educational process.

Therefore, the need for investigation in this area is felt by the researcher and planned to see the relationship between thinking styles and personality of the adolescences.

\section{Objective}

To study the thinking styles of adolescences in relation to their personality types.

\section{Hypotheses}

1. There will be significant difference in Legislative Style of thinking of Adolescences having extrovert and introvert type of personality.

2. There will be significant difference in Executive Style of thinking of Adolescences having extrovert and introvert type of personality.

3. There will be significant difference in Judicial Style of thinking of Adolescences having extrovert and introvert type of personality.

4. There will be significant difference in Monarchic thinking style of Adolescences having extrovert and introvert type of personality.

5. There will be significant difference in Hierarchic Style of thinking of Adolescences having extrovert and introvert type of personality.

6. There will be significant difference in Oligarchic Style of thinking of Adolescences having extrovert and introvert type of personality.

7. There will be significant difference in Anarchic thinking style of Adolescences having extrovert and introvert type of personality.

8. There will be significant difference in Global thinking style of Adolescences having extrovert and introvert type of personality.

9. There will be significant difference in Local thinking style of Adolescences having extrovert and introvert type personality.

10. There will be significant difference in Internal thinking style of Adolescences having extrovert and introvert type personality.

11. There will be significant difference in External thinking style of Adolescences having extrovert type and introvert type personality.

12. There will be significant difference in Liberal thinking of Adolescences having extrovert and introvert type personality.

13. There will be significant difference in Conservative thinking style of Adolescences having extrovert and introvert type personality.

Method

\section{Methodology}

In the present research, the Normative Survey method was used.

\section{Sample}

For the purposes of the study, 371 adolescences of senior secondary schools of Aligarh district of Uttar Pradesh were selected from the total cluster of the adolescences by using accidental technique of sample selection. Stream and Gender wise details of the sample have been given in Table -1 .

Table 1 - Stream and Gender wise structure of the Sample

\begin{tabular}{|l|l|l|l|l|l|}
\hline Stream & Gender & \\
\hline Science & Arts & Commerce & Male & Female & Total \\
\hline 193 & 106 & 72 & 198 & 173 & 371 \\
\hline
\end{tabular}




\section{Variables}

In the presented study, two types of variables were considered:

1. Independent variable - Personality (Extrovert and Introvert)

2. Criterion variable - Thinking Styles (Legislative, Executive, Judicial, Monarchic, Hierarchic, Oligarchic, Anarchic, Global, Local, Internal, External, Liberal and Conservative)

Tools

In the present study the following tools were employed for data collection :

$>$ Thinking Style Inventory (by Sternberg and Wagner)

Maudsley Personality Inventory (M P I) (by Eysenck)

\section{Statistical Techniques}

The data were analyzed by the use of various statistical techniques viz; Mean, Standard Deviation and Critical Ratio.

\section{Results And Discussion}

To study the effect of personality of the adolescences on their thinking style, first of all, the total sample of adolescences was categorized into two groups on the basis of personality. To formulate these two groups, $\mathrm{M} \pm 1 \mathrm{SD}$ formula was applied on scores. Subjects scoring $\mathrm{M}+\mathrm{SD}$ and above were classified as high extraversion (extroverts) and those who scored M-SD and below were classified as low introversion (introverts). To make a comparison between these groups of adolescences, critical ratio test was applied to test the significance of the difference between the means of thirteen thinking styles of the two groups. The results obtained are presented below -

Table 2 - Significance of difference in mean scores of thirteen thinking Style in respect of Extrovert and

\begin{tabular}{|c|c|c|c|c|c|c|c|}
\hline \multicolumn{8}{|c|}{ Introvert Adolescences } \\
\hline $\begin{array}{l}\text { Dimensions of Thinking } \\
\text { Styles }\end{array}$ & Group & $\mathbf{N}$ & Mean & S.D. & df & 't' value & $\mathbf{p}$ \\
\hline \multirow{2}{*}{ Legislative Style } & Extrovert & 53 & 41.4 & 7.17 & \multirow{2}{*}{120} & \multirow{2}{*}{0.509} & \multirow{2}{*}{$>.05$} \\
\hline & Introvert & 69 & 42.06 & 7.01 & & & \\
\hline \multirow{2}{*}{ Executive Style } & Extrovert & 53 & 41.87 & 7.16 & \multirow{2}{*}{120} & \multirow{2}{*}{0.966} & \multirow{2}{*}{$>.05$} \\
\hline & Introvert & 69 & 40.59 & 7.37 & & & \\
\hline \multirow{2}{*}{ Judicial Style } & Extrovert & 53 & 37.02 & 6.49 & \multirow{2}{*}{120} & \multirow{2}{*}{1.448} & \multirow{2}{*}{$>.05$} \\
\hline & Introvert & 69 & 38.78 & 6.08 & & & \\
\hline \multirow{2}{*}{ Monarchic style } & Extrovert & 53 & 34.00 & 7.30 & \multirow{2}{*}{120} & \multirow{2}{*}{0.02} & \multirow{2}{*}{$>.05$} \\
\hline & Introvert & 69 & 33.97 & 9.06 & & & \\
\hline \multirow[b]{2}{*}{ Hierarchic Style } & Extrovert & 53 & 43.30 & 7.01 & \multirow{2}{*}{120} & \multirow{2}{*}{0.162} & \multirow[b]{2}{*}{$>.05$} \\
\hline & Introvert & 69 & 43.51 & 7.26 & & & \\
\hline \multirow{2}{*}{ Oligarchic Style } & Extrovert & 53 & 31.28 & 6.29 & \multirow{2}{*}{120} & \multirow{2}{*}{0.456} & \multirow{2}{*}{$>.05$} \\
\hline & Introvert & 69 & 31.84 & 7.24 & & & \\
\hline \multirow{2}{*}{ Anarchic style } & Extrovert & 53 & 35.74 & 6.33 & \multirow[b]{2}{*}{120} & \multirow[b]{2}{*}{1.125} & \multirow[b]{2}{*}{$>.05$} \\
\hline & Introvert & 69 & 34.25 & 8.30 & & & \\
\hline \multirow[b]{2}{*}{ Global style } & Extrovert & 53 & 33.81 & 6.89 & \multirow{2}{*}{120} & & \\
\hline & Introvert & 69 & 33.77 & 7.48 & & 0.031 & $>.05$ \\
\hline & Extrovert & 53 & 34.6 & 6.75 & & & \\
\hline Local style & Introvert & 69 & 35.82 & 8.34 & 120 & 0.894 & $>.05$ \\
\hline & Extrovert & 53 & 35.08 & 8.55 & & & \\
\hline Internal Style & Introvert & 69 & 35.70 & 8.6 & 120 & 0.396 & $>.05$ \\
\hline Fvternol Stule & Extrovert & 53 & 38.66 & 9.69 & 120 & 1384 & $>05$ \\
\hline External Style & Introvert & 69 & 41.00 & 8.67 & 120 & 1.384 & $>.05$ \\
\hline & Extrovert & 53 & 41.09 & 8.95 & 120 & & \\
\hline Liberal Style & Introvert & 69 & 42.04 & 8.54 & 120 & 0.613 & $>.05$ \\
\hline & Extrovert & 53 & 30.98 & 8.14 & & 0805 & $>05$ \\
\hline Conservative style & Introvert & 69 & 32.16 & 7.88 & 120 & 0.805 & $>.05$ \\
\hline
\end{tabular}

Table. 2 shows that the ' $t$ '-value for testing the significance of difference between the means of legislative thinking style was found to be 0.509 which is not significant ( $p>0.05)$. This lead to the rejection of the hypothesis-1. It means that extrovert type and introvert type Adolescences did not differ significantly on legislative thinking style. In other words, both the groups were almost equal with legislative thinking style.

It is evident from table-2 that ' $t$ ' value obtained as 0.966 , which is less than the tabled value of ' $t$ '. Hence it was non-significant. From this it may be inferred that the research hypothesis -2 was rejected. It may be interpreted to mean that there was no significant difference between extrovert type and introvert type Adolescences on executive thinking style. Both the groups were at par on his thinking style.

It is clear from the table-2 that the obtained ' $t$ '-value (1.448) is non-significant ( $p>0.05$ ). This suggests that there was no significant difference between extrovert type and introvert type Adolescences on judicial thinking style. 
A look at the mean values of the two groups reveals that perhaps introvert type Adolescences were more judicial thinking style prone, but it was because of chance factor. Hence it cannot be taken as true. Since the mean difference was not statistically significant, the research hypothesis-3 was rejected.

It is apparent from the table- 2 that ' $t$ '-value for monarchic thinking style came out to be 0.020 which is too little the value to become significant at 0.05 level. Thus leads to the conclusion that the research hypothesis 4 was rejected, which stated that there is significant difference in monarchic style of extrovert and introvert type Adolescences. It may be said that the groups were at par on monarchic thinking style.

It may be seen in table -2 that the ' $t$ '-value came out to be 0.162 , which is non-significant $(\mathrm{p}>0.05)$. This leads to the inference that there was no significant difference in hierarchic style of thinking in respect of extrovert and introvert type Adolescences. Hence the research hypothesis -5 was rejected.

It may be observed in table- 2 that the observed ' $t$ '-value (0.456) remained below the desired level of tabled ' $t$ '-value. Hence it was non-significant. From this it may be said that extrovert and introvert type Adolescences did not show any significant difference in their mean scores of oligarchic style of thinking. Alternatively, it may be stated that both the groups were alike with regard to oligarchic style of thinking. Hence the research hypothesis - 6 was rejected.

It is evident from the table-2 that ' $\mathrm{t}$ '-value for anarchic thinking style came out to be 1.125 , which is not significant at 0.05 level. Hence it leads to the conclusion that the research hypothesis -7 was not accepted which stated that there is significant difference in anarchic thinking style of extrovert and introvert type Adolescences. Thus it may be said that both the groups were equally anarchic in their thinking style.

It is clear from the table -2 that ' $t$ '-value came out to be 0.031 which too small to be significant at 0.05 level of significance $(\mathrm{p}>0.05)$. It may thus be inferred that there was no significant difference in global style of thinking in respect of extrovert type and introvert type Adolescences. Hence the concerned research hypothesis was rejected.

Table-2 clarifies that the obtained ' $t$ '-value (0.894) is non-significant ( $\mathrm{p}>0.05)$. It suggests that there was no significant difference in extrovert type and introvert type Adolescences with respect to their local style of thinking. The mean value scores however reveals that introvert type Adolescences are more local than extrovert type in local thinking style. It may be anticipated to chance factor. Since the mean difference was not statistically significant, the concerned research hypothesis was rejected.

The ' $t$ '-value of internal thinking style as reported in table- 2 is 0.396 , which is not significant at 0.05 level of confidence. From this it may be inferred that the research hypothesis stating that there will be significant difference in internal thinking style of extrovert and introvert type Adolescences was rejected. Hence it may be concluded that both the groups were at par in this thinking style.

Table- 2 shows that the obtained ' $t$ '-value of external thinking style was found to be 1.384 , which is statistically not significant $(\mathrm{p}>0.05)$. It leads to the rejection of the research hypothesis-11. It implies that extrovert type and introvert type Adolescences did not differ significantly in external thinking style. In other words, both groups show equal preference to external style of thinking.

It is evident from the table-2 that ' $t$ '-value obtained was 0.613 , which is less than the tabled value of ' $t$ '. Hence it was non-significant. Hence the research hypothesis-12 was rejected. Thus it may be concluded that there was no significant difference between extrovert type and introvert type Adolescences in liberal thinking style.

Table-2 exhibits that the ' $t$ '-value for conservative style of thinking was obtained as 0.805 , which is not significant at 0.05 level thereby rejecting the concerned research hypothesis. It means that there was no significant difference between extrovert type and introvert type Adolescences on conservative style of thinking.

Thus, on the basis of the above analysis it can be concluded that Extrovert and introvert type of Adolescences did not exhibit significant differences in their all thinking styles namely - integrated, legislative, executive, judicial, monarchic, hierarchic, oligarchic, anarchic, global, local, internal, external, liberal and conservative style of thinking.

The analysis of the data pointed out that Adolescences having introvert and extrovert type personality were found to be significantly different on only one thinking style i.e. Executive style. Neurotic type Adolescences were significantly higher on executive style than stable type Adolescences. Hiller's (1986) study gives some support to the findings of this study. He found that extroverted people exhibit more right hemispheric style than both normal and introverted persons. Jackobson's (1993) study comes on rescue indirectly which concluded that there was positive correlation between innovative style and extraversion type of personality. 


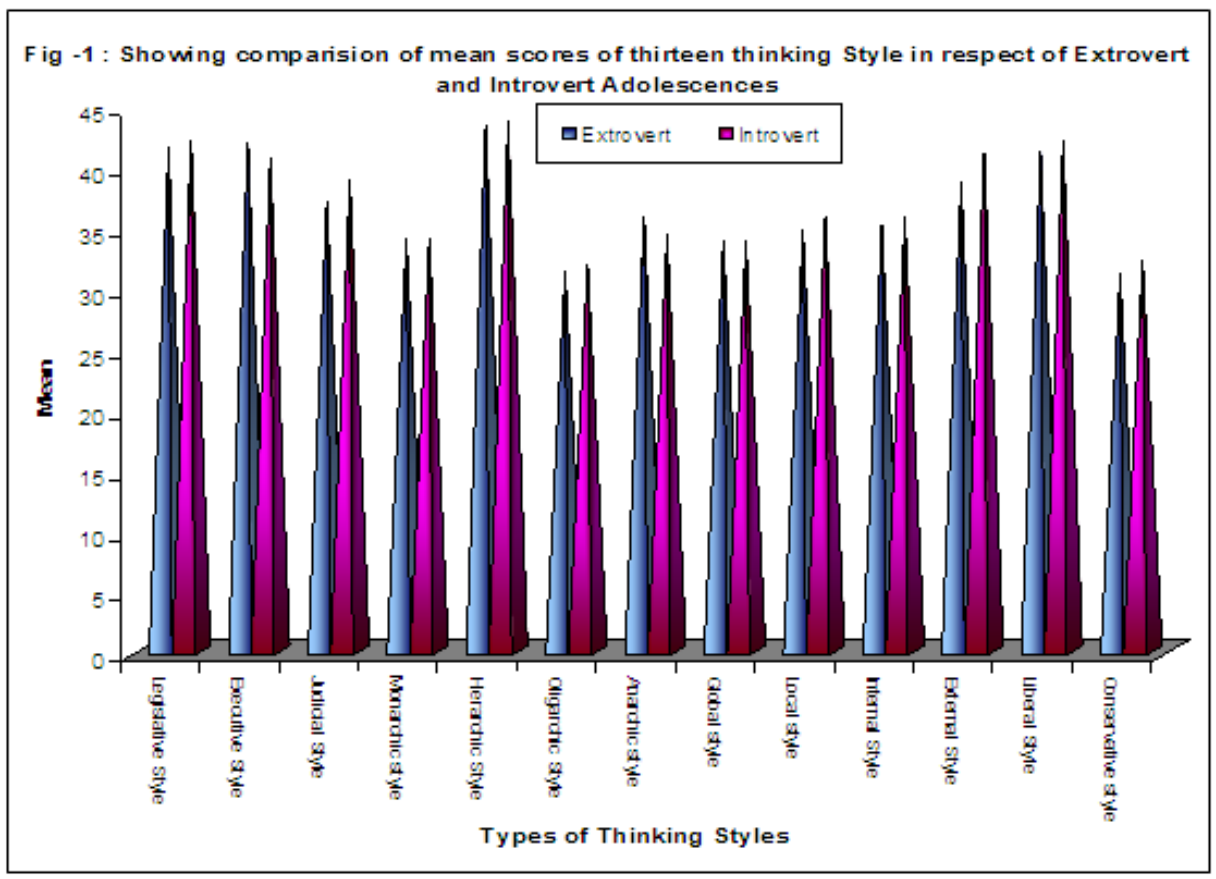

\section{Educational Implications}

On the basis of findings of the study, the following implications may be drawn for higher education. Thinking styles have effect on the extrovert and introvert type of personalities of the Adolescences. This fact may thus be considered by the teachers inside and outside classroom situations for modifying the student's personality.

Classroom transactions, curriculum framing, assignment designing may be based on thinking styles of Adolescences so that diversity in thinking styles of Adolescences may be properly exploited for their development.

\section{References}

[1]. Allport, G. W. (1961). Pattern and Growth in Personality. NYC Holt.

[2]. Best, J. W. and Kahn, J. V. (1996). Research in Education, (7th Ed.) New Delhi, Prentice-Hall of India

[3]. Cloninger, C. R. (2008). On well-being: Current research trends and future directions. Medicine, Mental Health, Science, Religion, and Well-Being, MSM, 6 (1), 3-9

[4]. Fer, S. (2005). Validity and reliability study of the thinking styles inventory. Kuram ve Uygulamada Eğitim Bilimleri, 5 (2), 433 461 .

[5]. Hudson, L. (1966). Contrary Imagination, Harmondsworth, Penguin.

[6]. Kao, G. YM., Lei, PL., \& Sun, CT. (2007). Thinking style impacts on web search strategies. Computers in Human Behavior, 24 (4), 1330-1341.

[7]. Sternberg, R. J. (1990). Thinking Styles: Keys to Understand Student Performance. Phil Delta Kappan, 71,336-371.

[8]. Sternberg, R. J. (2009). Thinking styles. New York: Cambridge University Press.

[9]. Sternberg, R. J. and Grigorenko, E, L. (1993). Thinking Styles and the Gifted. Roeper Review, 16(2):122-130.

[10]. Sternberg, R. J. and Wagner, R. (1991). Thinking Styles Inventory. Tallahasses, F.I. Star Mountain Projects. Inc.

[11]. William, C. and Kuzmich, N. (1985). Learning and Thinking Styles of Prospective Teachers, Journal of Creative Behaviour, Vol. 19(3), 223-224.

[12]. Zhang, LF. \& Sternberg, R. J. (2001). Perspectives on thinking, learning and cognitive styles. London: Lawrence Erlbaum Associates.

[13]. Zhang, LF. \& Sternberg, R. J. (2006). The nature of intellectual styles. London: Lawrence Erlbaum Associates. 